\title{
Study of Seroprevalence of HIV, Hepatits B and C And Syphilis Among Blood Donors In A Tertiary Care Hospital, Kolkata
}

\author{
Dr. Sukla Naskar ${ }^{1}$, Dr. Sumit Nandy ${ }^{2}$, Prof. Keya Basu ${ }^{3}$, Dr. Rivu Basu ${ }^{4}$ \\ 1 Assistant Professor, Dept of Pathology, Calcutta National Medical College, Kolkata, West Bengal, India \\ 2 Demonstrator, Dept of Pathology, Calcutta National Medical College \\ 3 Professor and Head, Dept of Pathology, Calcutta National Medical College \\ 4 Assistant Professor, Dept of Community Medicine, R G Kar Medical College, Kolkata
}

\begin{abstract}
Transfusion transmitted infections (TTIs) are a real concern worldwide. Blood transfusion is an important mode of transmission of infections to recipients.

The aim of our study was to assess the prevalence of transfusion transmitted infection among blood donors, a 10years retrospective study, from April 2002 to March2012 was conducted at the blood bank of Calcutta National Medical College and Hospital, Kolkata, West Bengal. Donors were screened routinely for seroprevalence of HIV, HBV, HCV and syphilis and malaria. Our study was focused on mainly HIV, Hepatitis and syphilis. A total of 128119 donors were tested, out of which $523(0.40 \%)$ were replacement donors and $127596(99.59 \%)$ were voluntary donors. The seroprevalence of HIV was $0.28 \%$ in the donors. The seroprevalence of $\mathrm{HBV}, \mathrm{HCV}$ and syphilis was $1.75 \%, 0.37 \%$ and $0.44 \%$ respectively in total donors. Seroprevalence of $H B V, H C V$, and HIV in voluntary blood donors is high throughout this study.

Key words: TTI, Blood donors, Hepatitis, HIV, Seroprevalence, Prevention
\end{abstract}

\section{Introduction:}

Blood transfusion forms an integral part of modern mode of therapy. Transmission of infectious diseases through donated blood is of concern to blood safety. Blood transfusion carries the risk of transfusiontransmissible infections, including HIV, hepatitis, syphilis, malaria and infrequently toxoplasmosis, and some viral infections like CMV, EBV and herpes. With every unit of blood, there is $1 \%$ chance of transfusionassociated problems including transfusion-transmitted diseases. ${ }^{[1]}$ Among the TTIs, hepatitis B (HBV), hepatitis $\mathrm{C}(\mathrm{HCV})$, and HIV are the most dreadful. 2 billion people have been infected with $\mathrm{HBV}$ and 360 million have chronic infection worldwide and it is the $10^{\text {th }}$ leading cause of death worldwide causing 500000 to 1.2 million deaths per year due to chronic hepatitis, cirrhosis, and hepatocellular carcinoma. ${ }^{[2],\left[{ }^{3]}\right.}$ In Asia and most of Africa, chronic HBV infection is common and in Western countries, the disease is relatively rare. ${ }^{[3]}$ Nearly 3.9 million people are estimated to be infected with $\mathrm{HCV}$, the most common chronic blood-borne infection, leading to 8000 to 10000 deaths annually in USA. ${ }^{[4]}$ The Indian subcontinent is classified as an intermediate HBV endemic (HBsAg carriage 2-7\%) zone and has the second largest global pool of chronic HBV infections. ${ }^{[3]}$ The improved screening and testing of blood donors has significantly reduced transfusion-transmitted diseases in most developed countries. This has not been so in developing nations. Poor health education and lack of awareness result in the reservoir of infections in the population.

The aim of our study was to know the seroprevalence of transfusion-transmitted infections in donors screened in blood bank in $\mathrm{CNMCH}$, Kolkata.

\section{Materials And Methods:}

This cross-sectional observational study was done among voluntary and replacement blood donors who attended blood bank of CNMCH or blood donation camps during the period of April 2002 to March 2012.

In this we included followings : (1) subjects of either sex, (2) age group (in years) - 18 to 60, and (3) subjects otherwise healthy for blood donation.

The screening for HIV was done by ELISA using kits (Monozyme; J. Mitra, India). $\mathrm{Hb}_{\mathrm{S}} \mathrm{Ag}$ was detected by ELISA (Transasia, India and J. Mitra, India). Anti-HCV test was done by ELISA (Monozyme, J Mitra, India and Transasia, India). Test for syphilis was done by RPR (Mediclone, India and Tulip, India). Statistical analysis done by Chi-square test where $\mathrm{p}$ value less than 0.001 . 


\section{Results:}

Table 1.Yearwise distribution and seroprevalence of TTI among the donors

\begin{tabular}{|l|l|l|l|l|l|l|l|}
\hline $\begin{array}{l}\text { YEAR(APRIL- } \\
\text { MARCH) }\end{array}$ & $\begin{array}{l}\text { VOLUNTARY } \\
\text { DONOR }\end{array}$ & $\begin{array}{l}\text { REPLACEMENT } \\
\text { DONOR }\end{array}$ & $\begin{array}{l}\text { TOTAL } \\
\text { DONOR }\end{array}$ & HIV & HBV & HCV & $\begin{array}{l}\text { RPR } \\
\text { (SYPHILIS) }\end{array}$ \\
\hline $2002-2003$ & 7490 & 20 & 7510 & 28 & 107 & 6 & 26 \\
\hline $2003-2004$ & 9674 & 14 & 9688 & 44 & 130 & 21 & 41 \\
\hline $2004-2005$ & 8207 & 28 & 8235 & 24 & 109 & 18 & 36 \\
\hline $2005-2006$ & 9358 & 24 & 9382 & 35 & 187 & 31 & 29 \\
\hline $2006-2007$ & 9997 & 32 & 10029 & 37 & 240 & 36 & 39 \\
\hline $2007-2008$ & 10455 & 33 & 10488 & 44 & 293 & 58 & 44 \\
\hline $2008-2009$ & 14007 & 58 & 14065 & 23 & 332 & 65 & 74 \\
\hline $2009-2010$ & 16374 & 78 & 16452 & 45 & 359 & 68 & 51 \\
\hline $2010-2011$ & 20201 & 27 & 20228 & 41 & 190 & 85 & 40 \\
\hline $2011-2012$ & 21833 & 209 & 128119 & 395 & 2247 & 485 & 565 \\
\hline Total & 127596 & 523 & & 0.28 & 1.75 & 0.37 & $0.44 \%$ \\
\hline$\%$ & $0.40 \%$ & & $\%$ & \\
\end{tabular}

Table 2. Yearwise distribution of donors having TTI according to described age groups

\begin{tabular}{|c|c|c|c|c|c|}
\hline YEAR(APRIL-MARCH) & AGE(YRS) & HIV & HBV & $\mathrm{HCV}$ & RPR \\
\hline \multirow[t]{2}{*}{$2002-2003$} & $18-35$ & 16 & 78 & 04 & 14 \\
\hline & $36-60$ & 12 & 29 & 2 & 12 \\
\hline \multirow[t]{2}{*}{$2003-2004$} & $18-35$ & 28 & 95 & 15 & 21 \\
\hline & $36-60$ & 16 & 35 & 06 & 20 \\
\hline \multirow[t]{2}{*}{$2004-2005$} & $18-35$ & 15 & 76 & 13 & 19 \\
\hline & $36-60$ & 09 & 33 & 05 & 17 \\
\hline \multirow[t]{2}{*}{$2005-2006$} & $18-35$ & 20 & 147 & 23 & 14 \\
\hline & $36-60$ & 15 & 40 & 08 & 15 \\
\hline \multirow[t]{2}{*}{$2006-2007$} & $18-35$ & 24 & 182 & 28 & 20 \\
\hline & $36-60$ & 13 & 58 & 08 & 19 \\
\hline \multirow[t]{2}{*}{$2007-2008$} & $18-35$ & 30 & 227 & 44 & 24 \\
\hline & $36-60$ & 14 & 66 & 14 & 20 \\
\hline \multirow[t]{2}{*}{$2008-2009$} & $18-35$ & 16 & 240 & 40 & 36 \\
\hline & $36-60$ & 07 & 92 & 25 & 38 \\
\hline \multirow[t]{2}{*}{$2009-2010$} & $18-35$ & 28 & 272 & 41 & 26 \\
\hline & $36-60$ & 17 & 87 & 27 & 25 \\
\hline \multirow[t]{2}{*}{$2010-2011$} & $18-35$ & 21 & 141 & 63 & 22 \\
\hline & $36-60$ & 20 & 49 & 22 & 18 \\
\hline \multirow[t]{2}{*}{$2011-2012$} & $18-35$ & 42 & 208 & 74 & 90 \\
\hline & $36-60$ & 32 & 92 & 23 & 95 \\
\hline
\end{tabular}

Table 3. Yearwise sex distribution of donors having TTI

\begin{tabular}{|c|c|c|c|c|c|c|}
\hline \multirow[t]{2}{*}{ Year(APRIL-MARCH) } & \multirow{2}{*}{$\begin{array}{l}\text { TOTAL } \\
\text { DONAR }\end{array}$} & MALE & \multirow{2}{*}{ HIV } & \multirow[t]{2}{*}{$\mathrm{HBV}$} & \multirow[t]{2}{*}{$\mathrm{HCV}$} & \multirow[t]{2}{*}{ RPR } \\
\hline & & FEMALE & & & & \\
\hline \multirow[t]{2}{*}{$2002-2003$} & \multirow{2}{*}{7510} & 6845 & 25 & 103 & 05 & 25 \\
\hline & & 165 & 03 & 04 & 01 & 01 \\
\hline \multirow[t]{2}{*}{$2003-2004$} & \multirow[t]{2}{*}{9688} & 7900 & 38 & 125 & 19 & 39 \\
\hline & & 1788 & 06 & 05 & 02 & 02 \\
\hline \multirow[t]{2}{*}{$2004-2005$} & \multirow[t]{2}{*}{8235} & 6890 & 20 & 106 & 17 & 33 \\
\hline & & 1345 & 04 & 03 & 01 & 03 \\
\hline \multirow[t]{2}{*}{$2005-2006$} & \multirow[t]{2}{*}{9382} & 8193 & 31 & 180 & 30 & 27 \\
\hline & & 1189 & 04 & 07 & 01 & 02 \\
\hline \multirow[t]{2}{*}{$2006-2007$} & \multirow[t]{2}{*}{10029} & 8609 & 34 & 232 & 34 & 37 \\
\hline & & 1420 & 03 & 08 & 02 & 02 \\
\hline \multirow[t]{2}{*}{$2007-2008$} & \multirow[t]{2}{*}{10488} & 9364 & 42 & 279 & 54 & 40 \\
\hline & & 1124 & 02 & 14 & 04 & 04 \\
\hline \multirow[t]{2}{*}{$2008-2009$} & \multirow[t]{2}{*}{14065} & 12296 & 22 & 316 & 60 & 66 \\
\hline & & 1769 & 01 & 16 & 05 & 08 \\
\hline \multirow[t]{2}{*}{$2009-2010$} & \multirow[t]{2}{*}{16452} & 14320 & 39 & 332 & 55 & 44 \\
\hline & & 2132 & 06 & 27 & 13 & 07 \\
\hline \multirow[t]{2}{*}{$2010-2011$} & \multirow[t]{2}{*}{20228} & 17192 & 36 & 178 & 68 & 33 \\
\hline & & 3036 & 05 & 12 & 17 & 07 \\
\hline \multirow[t]{2}{*}{ 2011-2012 } & \multirow[t]{2}{*}{22042} & 18434 & 67 & 267 & 75 & 133 \\
\hline & & 3608 & 07 & 33 & 22 & 52 \\
\hline
\end{tabular}


Table 4.Statistical analysis of donors as per the age and sex distribution (value in bold letters are statistically significant. Figures in brackets are percentages.)

\begin{tabular}{|l|l|l|l|l|l|}
\hline & Total & HIV & HBV & HCV & RPR \\
\hline Sex & & & & & \\
\hline Male & 110543 & $354(0.32)$ & $\mathbf{2 1 1 8 ( 1 . 9 2 )}$ & $417(0.38)$ & $477(0.43)$ \\
\hline Female & 17576 & $41(0.23)$ & $\mathbf{1 2 9 ( 0 . 7 3 )}$ & $68(0.39)$ & $88(0.50)$ \\
\hline Age & & & & & \\
\hline $18-35$ yrs & 89639 & $\mathbf{2 4 0 ( 0 . 2 7 )}$ & $\mathbf{1 6 6 6 ( 1 . 9 )}$ & $354(0.38)$ & $\mathbf{2 8 6 ( 0 . 3 2 )}$ \\
\hline $36-60$ yrs & 38480 & $\mathbf{1 5 5 ( 0 . 4 )}$ & $\mathbf{5 8 1 ( 1 . 5 )}$ & $140(0.36)$ & $\mathbf{2 7 9 ( 0 . 7 3 )}$ \\
\hline Total & 128119 & 395 & 2247 & 485 & 565 \\
\hline
\end{tabular}

A total 128119 blood donors were studied. Among them, majority, 1275969(99.59\%), were voluntary donors and 523(0.40\%), were replacement donors. Among the three viruses, prevalence wise, HBV outnumbered the other two. Prevalence of HBV was $1.75 \%$, whereas HCV, HIV and syphilis were $0.37 \%$, $0.28 \%$ and $0.44 \%$ respectively.

Among total donors (128119), male donors and female donors were 110543 \& 17576 respectively. Among male donors and female donors majority, 2118(1.92\%) \&129(0.73\%) were HBV positive respectively. Both were statistically significant ( $p$ value $<0.001$ ).

Total number of donors in age group 18-35 years and 36-60 years were $89639 \& 38480$ respectively. Among the age group 18-35 years HIV, HBV and Syphilis were positive in 240(0.27\%), 1666(1.9\%) and $286(0.32 \%)$ donors. These were statistically significant ( $\mathrm{p}$ value $<0.001)$.

Among the age group 36-60 years HIV, HBV and Syphilis were positive in $155(0.4 \%), 581(1.5 \%)$ and $279(0.73 \%)$ donors. These were statistically significant ( $\mathrm{p}$ value $<0.001)$.

\section{Discussion:}

Blood transfusion is a significant route of transmission of infectious disease like HBV, HCV, and HIV. These diseases are of great concern because they can cause fatal acute and chronic life-threatening disorders. Risk may be reduced by the vigorous screening of donors and donated blood. Prevalence of HBV, HCV, and HIV among the healthy blood donors or the replacement donors reflects the disease prevalence in the community. ${ }^{[5]}$ Due to limitation in current blood screening practices in developing countries, donation by such individual is a potential threat to recipients. ${ }^{[6]} \mathrm{A}$ WHO report states that the viral dose in HIV transmission through blood is so large that one HIV positive transfusion leads to death on an average after two years in children and after three to five years in adults. ${ }^{[7]}$ Blood donation collected in latent period of infection may be infectious despite of negative antibody test. ${ }^{[8]}$ The report of National AIDS control organization showed a considerable increase in HIV prevalence in the year 2005 in antenatal clinic $(0.5-0.84 \%)$ and sexually transmitted diseases clinic $(0.8-2.16 \%)$ from the state of West Bengal, whereas adult HIV prevalence in the rest of the country was comparable with the previous years. ${ }^{[9]}$ Seropositivity for HIV $(0.28 \%)$ in this study was lower than the studies reported from other parts of India \& also study done in Kolkata on 2010. ${ }^{[10],[11],[12][5]} \mathrm{A}$ slow and steady increase of HIV incidence in voluntary blood donors (from 1.6 per 1000 in 1988-1989 to 3.8 per 1000 in 1996-1997) was noted in Vellore. ${ }^{[13]}$ An increase in HIV incidence from 0.04 to $0.55 \%$ was shown in New Delhi between 1989 and 1995, whereas a decreasing trend of HIV incidence $(0.81 \%$ in $2006,0.32 \%$ in 2007 , and $0.53 \%$ in 2008, overall $0.51 \%$ ) was noted in blood donors of Bhopal and it is comparable with present study. ${ }^{[14],[15]}$ Incidence of HIV $(0.16-0.18 \%)$ in Kerala remained constant from 1990 to $1999 .{ }^{[16]}$ No voluntary blood donors were found to be HIV positive in Haryana. ${ }^{[17]}$

In India, detection of HBV infection among blood donors is carried out by HBsAg screening, while detection of anti-HBc is rarely done. ${ }^{[18]}$ In West Bengal, mandatory HCV screening started from June 2001. ${ }^{[5]}$ An increasing prevalence of HBV (1.28 - 1.66\%), HCV (0.28 - 0.35\%), and HIV (0.23 - 0.35\%) was observed in blood donors of Kolkata in 2004 to $2005 .{ }^{[19]}$ and in study done in 2010 in Kolkata where the prevalence of HBV, HCV, and HIV was $1.55 \%, 0.35 \%$, and $0.32 \%$, respectively. ${ }^{[5]}$ In the present study, TTIs were maintaining nearly the same prevalence (HBV: $1.75 \%$, HCV:0.37\%, HIV: $0.28 \%$ ) even in 2012.

In developed country like USA, the risk of HBV transmission through blood transfusion is 1: 63000 units transfused. ${ }^{[20]}$ Seroprevalence of HBV in other Indian studies had shown to range between 1.86 to $4.84 \%$, which was much higher than the prevalence of the present study. ${ }^{[21],[14],[22],[23]}$ An increasing incidence of HBV (2.6\% in 2006, 2.67\% in 2007, and 3.43\% in 2008 and overall - 2.9\%) was noted in blood donors of Bhopal. ${ }^{[15]}$

Voluntary blood donors of Chandigarh had $0.66 \%$ seropositivity of HBV. ${ }^{[24]}$ In different Indian studies, HCV seroprevalence ranged between 0.57 to $1.49 \%$, which was much higher than the present study $(0.35 \%)$. ${ }^{[16],[21],[14],[15],[24]}$

Majority of the donors were male (86.28\%), similar findings were also found in studies in different parts of India. ${ }^{[25],[13],[16][5]}$

The highest prevalence of HBsAg, HIV, HCV and syphilis infections occurred among commercial blood donors and those aged 18 to 47 years old, the most sexually active age group. ${ }^{[26]}$ This is also comparable with present study. 
Seroprevalence increased after the age of 30 years, though not linearly, with the highest rate $(3.2 \%)$ recorded in the 31-40 years and 51-70 years age.; age and gender of donors seem to be important factors affecting it. ${ }^{[27]}$

\section{Conclusion:}

In the 10- year period, 128119 donors were studied. Among them $99.96 \%$ were voluntary donors. Male donors constituted $86.28 \%$. Seroprevalence of HIV in total donors was $0.28 \%$. The sero-positivity of HBS $\mathrm{Ag}, \mathrm{HCV}$ and syphilis was $1.75 \%, 0.37 \%$ and $0.44 \%$ respectively. Proper pre donation screening of blood donor and post donation testing of blood bag should be done to minimize transfusion transmitted disease. We should educate the donors as well as medical staffs and makes awareness about transfusion transmitted diseases, so that we can provide safes blood as much as and to reduce transmitted disease to recipient.

\section{References:}

[1]. Widmann FK, editor. Technical manual American association of blood banks. Aglington USA: 1985. p. 325-44.

[2]. Shepard CW, Simard EP, Finelli L, Fiore AE, Bell BP. Hepatitis B virus infection: Epidemiology and vaccination. Epidemiol Rev 2006;28:112-25.

[3]. Lavanchy D. Hepatitis B virus epidemiology, disease burden, treatment, and current and emerging prevention and control measures: A review. J Viral Hepat 2004,11:97-107.

[4]. Gasiorowicz M, Hurrie M, Russel A, Hoxie N, Vegeront J. Epidemiologic trends in infection, mortality and transplants related to hepatitis C in Wisconsin. WMJ 2006;105:34-9.

[5]. Das BK, Gayen BK, Aditya S, Chakrovorty SK, Datta PK, Joseph A. Seroprevalence of Hepatitis B, Hepatitis C, and human immunodeficiency virus among healthy voluntary first-time blood donors in Kolkata. Ann Trop Med Public Health [serial online] 2011 [cited 2012 Jul 15];4:86-90.

[6]. Wienberger KM, Bauer T, Bohm S, Jilg W. High genetic variability of the group-specific a-determinant of hepatitis B virus surface antigen (HbSAg) and the corresponding fragment of the viral polymerase in chronic virus carriers lacking detectable HbSAg in serum. J Gen Virol 2000;81:1165-74.

[7]. Widmann Fk editor.Technical Manual American association of blood banks.Aglington USA:1985,p325-44

[8]. Cumming PD, Wallace EL, Schoor JB, Dodd RY. Exposure of patients to HIV through the transfusion of blood components that test antibody negative. N Engl J Med 1989;321:941-6.

[9]. National AIDS control Organization. Available from: URL http://www.nacoonline.org.[Last cited on 2010, Jun 14].

[10]. Ramanamma MV, Rfamani TV. A Preliminary report on the seroprevalence of HIV-2 in Vishakapatnam. Indian J Med Microbiol 1994;12:212-5.

[11]. Tallore SS, Shahapurkar A, Krishan BV. Prevalence of HIV infection among blood donors in North Karnataka. Indian J Med Microbiol 1997; 15:123-5.

[12]. Panda M, Kar K. HIV, hepatitis B and C infection status of the blood donors in a blood bank of a tertiary health care centre of Orissa. Indian J Public Health 2008;52(1):43-44

[13]. Rose D, Sudarsanam A, Padankatti T, Babu PG, John TJ. Increasing prevalence of HIV antibody among blood donors monitored over 9 years in one blood bank. Indian J Med Res 1998;108:42-4. 4

[14]. Nanu A Sharma SP, Chatterjee K, Jyoti P. Markers for transfusion-transmissible infections in north Indian voluntary and replacement blood donors: Prevalence and trends 1989-1996.Vox Sang1997;73:70-3. $¥$

[15]. Sawke N, Sawke GK, Chawla S. Seroprevalence of Common Transfusion - Transmitted infections among Blood Donors. People's Journal of Scientific Research. 2010;3(1):5-8. $₫$

[16]. Mathai J, Sulochana PV, Satyabhama S, Nair PK, Sivakumar S. Profile of transfusion transmissible infections and associated ri sk factors among blood donors of Kerala. Indian J Pathol Microbiol 2002;45:319-22

[17]. Arora D, Arora B, Khetarpal A. Seroprevalence of HIV, HBV, HCV and syphilis in blood donors in Southern Haryana. IJPM 2010;53:308-9. 4

[18]. Chattopadhyay S, Rao S, das BC, Sing NP, Kar P. Pervalence of transfusion transmitted virus infection in patients on maintenance hemodialysis from New Delhi, India. Hemodial Int 2005;9:362-66. $₫$

[19]. Bhattacharya P, Chandra PK, Datta S, Banerjee A, Chakraborty S, Rajendran K, et al. Significant increase in HBV, HCV, HIV and syphilis infections among blood donors in West Bengal, Eastern India 2004-2005: Exploratory screening reveals high frequency of occult HBV infection. World J Gastroenterol 2007;13:3730-33.

[20]. Schreiber GB, Busch MP, Kleinman SH, Korelitz JJ. The risk of transfusion-transmitted viral infections. N Engl J Med 1996;334:1685-90.

[21]. Shrikrishna A, Sitalakshmi S, Prema Damodar S. How safe are our safe donors? Indian J Pathol Microbiol 1999;42:411-6.

[22]. Garg S, Mathur DR, Garg DK. Comparison of seropositivity of HIV, HBV, HCV and syphilis in replacement and voluntary blood donors in western India. Indian J Pathol Microbiol 2001;44:409-12

[23]. Sonwane BR, Birare SD, Kulkarni PV. Prevalence of seroreactivity among blood donors in rural population. Indian J Med Sci 2003;57:405-7.

[24]. Gupta N, Kumar V, Kaur A. Seroprevalence of HIV, HBV, HCV and syphilis in voluntary blood donors. Indian J Med Sci 2004;58:255-7.

[25]. Rao P, Annapurna K. HIV status of blood donors and patients admitted in KEM Hospital Pune. Indian J Hemat Blood Transf 1994;12:174-6.

[26]. Fiekumo Igbida Buseri, Musa Abidemi Muhibi, Zaccheaus Awortu Jeremiah. Sero-epidemiology of transfusion-transmissible infectious diseases among blood donors in Osogbo, south-west Nigeria

[27]. C.U Odenigbo, C.O Oguejio et al. Prevalence Of Antibodies To Hepatitis C Virus In Blood Donors In Nnewi, South-Eastern Nigeria; In Association With Blood Groups. The Internet Journal of Gastroenterology ISSN: $1528-8323$ 